\title{
OPEN A new electrochemical strategy for the synthesis of a new type of sulfonamide derivatives
}

\author{
Hamed Goljani, Zahra Tavakkoli, Ali Sadatnabi, Mahmood Masoudi-khoram \& \\ Davood Nematollahi(iD
}

This study is the first report of electrochemical generation of hydroxyimino-cyclohexa-dien-ylidene haloniums and their application in the synthesis of new halo- $N$-hydroxysulfonamide derivatives. These compounds were obtained in a one-pot process based on the reaction of halonium acceptors with arylsulfinic acids. The method is easy to carry out, as it is performed using the carbon electrodes in a simple undivided cell. The protocol has a broad substrate scope with a tolerance for a variety of functional groups. The proposed mechanism is a ping-pong type reaction mechanism, which in its first stage the halonitroarene is reduced at the cathode to related hydroxylamine and in the second stage the cathodically generated hydroxylamine by oxidation at the anode and participating in disproportionation reaction is converted to the halonium acceptor.

Sulfonamides are a well-known and very important class of organic compounds because of their diverse biological and pharmacological activities ${ }^{1}$. These characteristics have developed, numerous strategies for the synthesis of sulfonamide derivatives. The most common method for the synthesis of sulfonamides is direct $\mathrm{N}-\mathrm{S}$ bond formation ${ }^{2-10}$. In addition, some sulfonamide derivatives were synthesized through electrochemical oxidation of amines in the presence of arylsulfinic acids ${ }^{11-15}$ or through electrochemical oxidative coupling of amines and thiols ${ }^{16,17}$. These are valuable methods, but they have the disadvantage that it uses aromatic amines which are toxic ${ }^{11-17}$. Other methods used in the synthesis of these compounds are the use of metal-catalysts for the synthesis of new sulfonamide derivatives (Fig. 1) ${ }^{18-26}$. These methods does not require the use of amines, but still have disadvantages such as the use of metal-catalysts and harsh workup conditions. From another point of view, to the best of our knowledge, no synthesis has been reported for halo- $N$-hydroxysulfonamide derivatives. This type of sulfonamide ( $N$-hydroxysulfonamide) has recently been used as a nitroxyl (HNO) donors in the management of acute decompensated heart failure ${ }^{27,28}$. These data led us to look for an efficient method without these drawbacks for the synthesis of some halo- $N$-hydroxysulfonamide derivatives.

So, we report here the first example of in situ generation and reaction of the unstable hydroxyiminocyclohexa-dien-ylidenehaloniums intermediates for the successful synthesis of new halo- $N$-hydroxy sulfonamide derivatives based on successive reduction and oxidation of halonitroarenes in the presence of arylsulfinic acids. It should be noted that the toxicity of nitro compounds is lower than similar amines ${ }^{29}$.

On the other hand, aromatic halonitro compounds were widely used in the synthesis of drugs, lumber preservatives, dyes, photographic chemicals, agrochemicals and flavorsm ${ }^{30}$. The first step in the synthesis of these compounds is hydrogenation of aromatic halonitro compounds mainly using transition metal catalysts ${ }^{31-33}$, while we have performed hydrogenation of halonitro compounds electrochemically without using transition metal catalysts. Aromatic halonitro compounds are also attractive because they have a $\pi$ donor and a $\sigma$ acceptor halogen atom and also an electron-withdrawing nitro group in their structure. These features as well as the absence of electrochemical data on these compounds, have also led us to understand the electrochemical properties of aromatic halonitro compounds, as another goal of this study. Synthesis of a new class of compounds which has not yet been synthesized electrochemically, in situ generation of the unstable hydroxyimino-cyclohexa-dienylidenehaloniums intermediates, for the first time, report of a novel reaction mechanism for the formation of halo- $N$-hydroxysulfonamide compounds, which has not been reported elsewhere and report a sustainable and efficient protocol for the synthesis of a new type of organic compounds are important aspect of this work. 

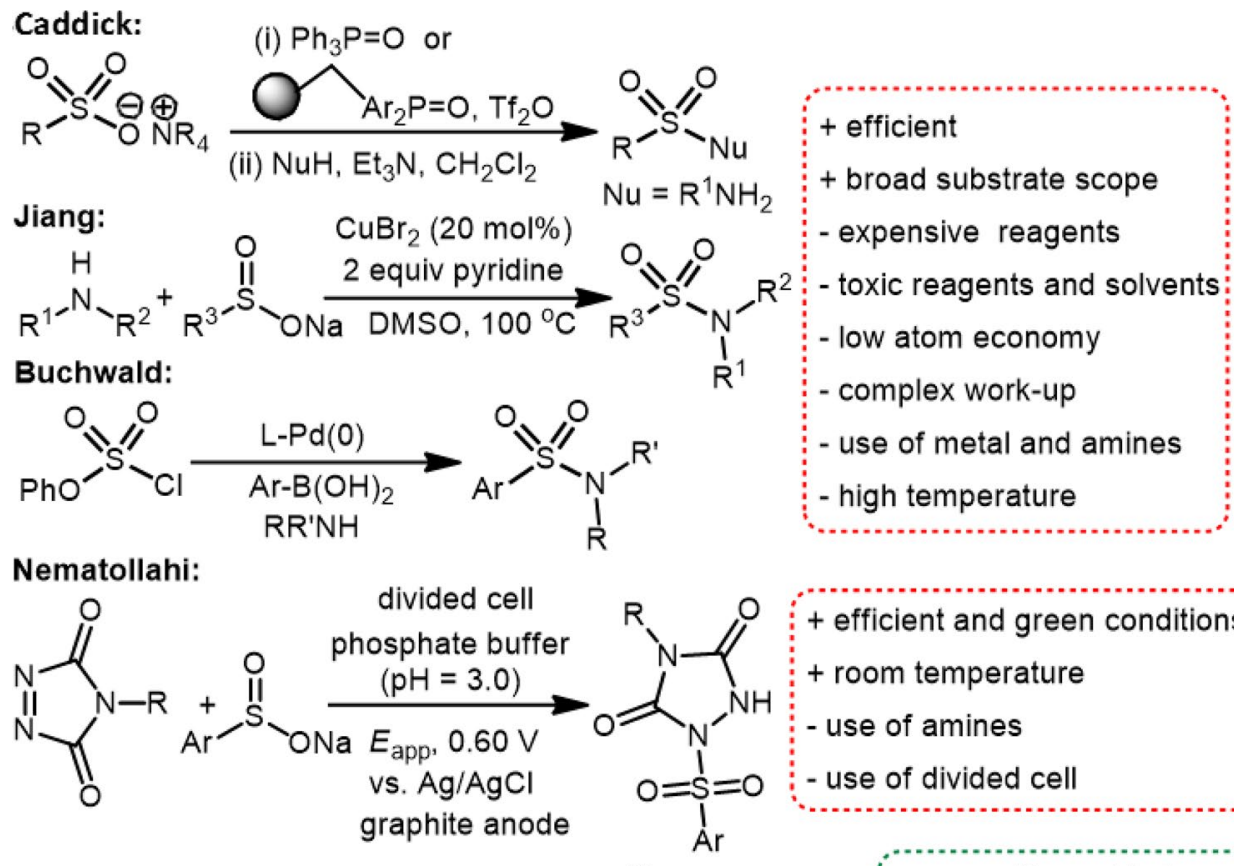

This work:
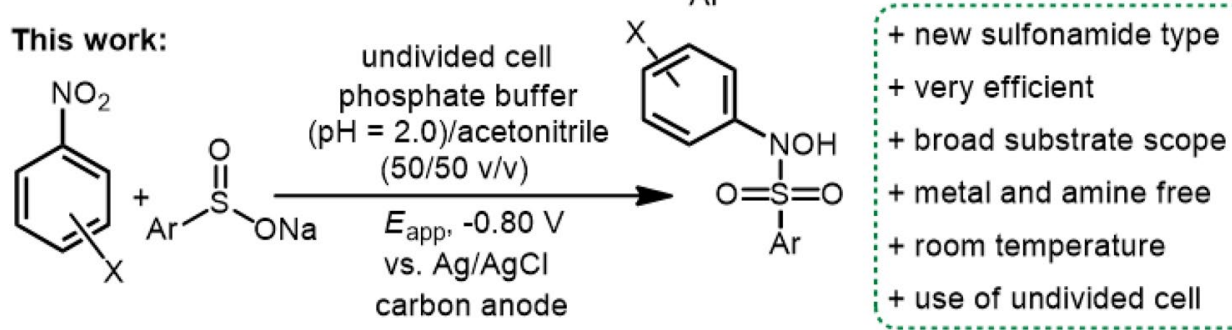

Figure 1. Overview of the synthesis of sulfonamide derivatives. The structures of the compounds were drawn using ChemOffice 12.0 (CambridgeSoft).

\section{Materials and methods}

A $\mu$-Autolab model PGSTAT 20 potentiostat/galvanostat (Metrohm-Autolab, Netherland) was used for the preparative electrolysis, cyclic voltammetry, differential pulse voltammetry and controlled potential coulometry experiments. The cell system consisted of a glassy carbon disc with diameter of $3.0 \mathrm{~mm}$, a platinum rod and an $\mathrm{Ag} / \mathrm{AgCl}(3 \mathrm{M})$ were used as working, counter and reference electrodes, respectively. The cathode used in macroscale electrolysis (synthesis) was an assembly of four carbon rods with of $32 \mathrm{~cm}^{2}$ area, while the anode consisted of a carbon rod with an area of $8 \mathrm{~cm}^{2}$. All electrodes were from AZAR Electrodes, (Iran). $p$-iodonitrobenzene, $o$-iodonitrobenzene, $p$-chloronitrobenzene and $p$-bromonitrobenzene were synthesized according to previously described methods ${ }^{34,35}$. $p$-Toluenesulfinic acid sodium salt (97\%), benzensulfinic acid sodium salt (97\%), p-chlorosulfinic acid sodium salt, acetic acid (99\%), perchloric acid (70\%) and phosphoric acid (85\%) were obtained from Sigma-Aldrich.

Experimental procedures. General procedure for synthesis of $1 b-3 b, 1 c-3 c, 1 d-3 d$ and $1 e-2 e$. In an undivided cell equipped with four carbon rods as cathode and one carbon rod as anode, a solution (ca. $80 \mathrm{~mL})$ of water (phosphate buffer, $\mathrm{pH}, 2.0, c=0.2 \mathrm{M}$ )/acetonitrile or DMF $(50 / 50 \mathrm{v} / \mathrm{v})$ containing halonitrobenzene $(0.5 \mathrm{mM})$ and arylsulfinic acid $(0.5 \mathrm{mM})$ was electrolyzed at $-0.8 \mathrm{~V} v s$. $\mathrm{Ag} / \mathrm{AgCl}$. The electrolysis was terminated when the current decayed to $5 \%$ of its original value. At the end of the electrolysis, the cell was placed overnight. The precipitated pale yellow was collected by filtration and purified by thin layer chromatography ( $n$-hexane/ ethyl acetate 4/1).

Characteristic of the products. $\quad N$-Hydroxy-N-(4-iodophenyl) benzenesulfonamide (1b) Pale yellow; MP: 108-110 ${ }^{\circ} \mathrm{C}$; ${ }^{1} \mathrm{H}$ NMR: $\delta$ ppm $\left(500 \mathrm{MHz}, \mathrm{CD}_{3} \mathrm{CO}-d_{3}\right): 6.99(\mathrm{~d}, J=10 \mathrm{~Hz}, 2 \mathrm{H}$, aromatic), $7.56(\mathrm{~m}, 4 \mathrm{H}$, aromatic), $7.66\left(\mathrm{~d}, J=10 \mathrm{~Hz}, 2 \mathrm{H}\right.$, aromatic), $7.73\left(\mathrm{~m}, 1 \mathrm{H}\right.$, aromatic), $10.21(\mathrm{~s}, 1 \mathrm{H}, \mathrm{OH}) ;{ }^{13} \mathrm{C} \mathrm{NMR}: \delta \mathrm{ppm}(125 \mathrm{MHz}$, $\mathrm{CD}_{3} \mathrm{CO}-d_{3}: 91.2,124.5,128.6,129.5,132.8,134.0,137.3,143.0$; IR $(\mathrm{KBr})\left(\mathrm{cm}^{-1}\right): 3334$ (medium, O-H), 1477 (medium $\mathrm{C}=\mathrm{C}$ ), 1340 and 1165 (strong, $\mathrm{S}=\mathrm{O}), 1084,999,685,593,572 ; \mathrm{MS}(\mathrm{m} / z)(\mathrm{EI}, 70 \mathrm{eV})$ (relative intensity): 218 (100), 77 (100), 359 (80), 141 (50), 374 (M, 25).

$\mathrm{N}$-Hydroxy- $\mathrm{N}$-(4-iodophenyl)-4-methylbenzenesulfonamide (2b) Pale yellow; MP: $157-158{ }^{\circ} \mathrm{C} ;{ }^{1} \mathrm{H}$ NMR: $\delta \mathrm{ppm}$ (500 MHz, $\mathrm{CD}_{3} \mathrm{CO}-d_{3}$ ): 2.42 (s, $3 \mathrm{H}$, methyl), 6.99 (d, $J=10,2 \mathrm{H}$, aromatic), 7.35 (d, $J=10 \mathrm{~Hz}, 2 \mathrm{H}$, aromatic), 7.43 

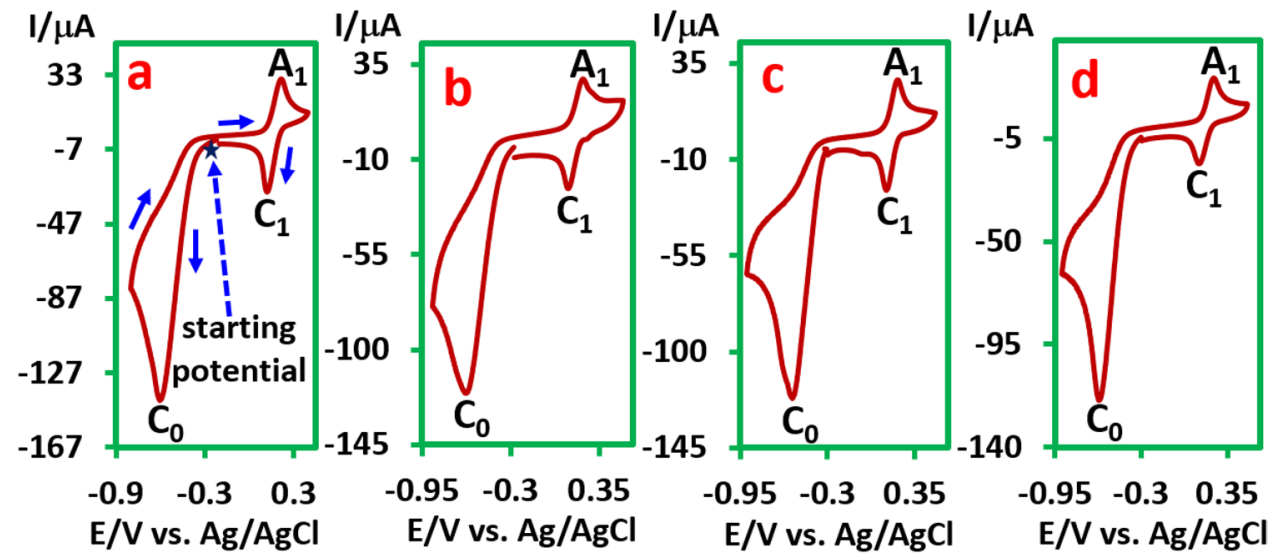

Figure 2. Cyclic voltammograms of $1.0 \mathrm{mM}$ (a) PINB, (b) PCNB, (c) PBNB and (d) OINB in aqueous phosphate buffer $(\mathrm{pH}, 2.0, c=0.2 \mathrm{M}) /$ acetonitrile $(50 / 50 \mathrm{v} / \mathrm{v})$ at GC electrode. Scan rate: $100 \mathrm{mV} / \mathrm{s}$ at room temperature. This figure was prepared by Microsoft Excel (OFFICE 2013).

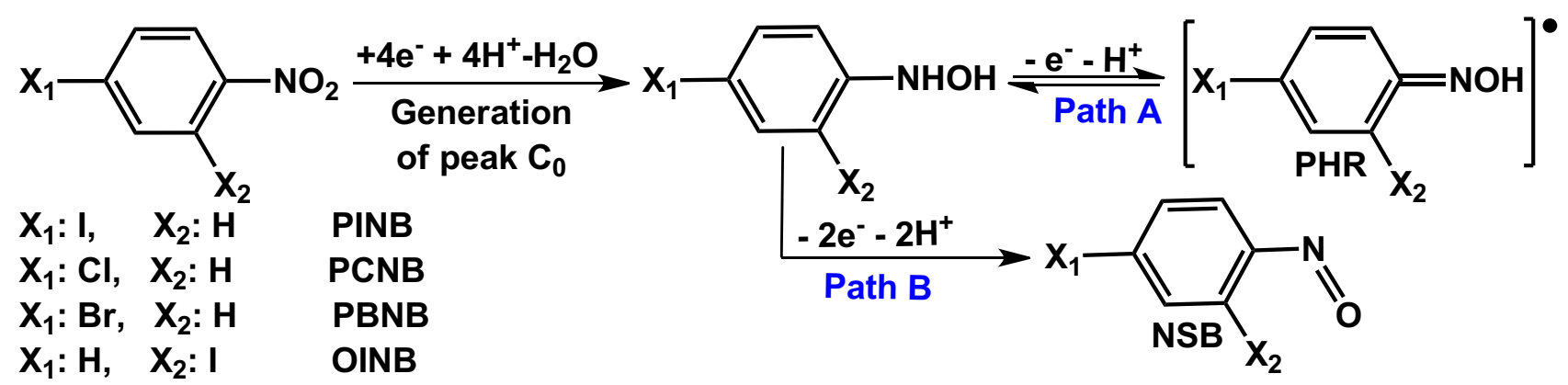

Figure 3. Electrochemical reactions of halonitroarenes. The structures of the compounds were drawn using ChemOffice 12.0 (CambridgeSoft).

(d, $J=10 \mathrm{~Hz}, 2 \mathrm{H}$, aromatic), $7.66(\mathrm{~d}, J=10 \mathrm{~Hz}, 2 \mathrm{H}$, aromatic), 10.30 (s, $1 \mathrm{H}, \mathrm{OH}) ;{ }^{13} \mathrm{C}$ NMR: $\delta$ ppm $(125 \mathrm{MHz}$, $\mathrm{CD}_{3} \mathrm{CO}-d_{3}: 20.7,91.0,124.5,128.6,129.1,129.5,130.0,137.2,138.1,143.1,145.0 ; \mathrm{IR}(\mathrm{KBr})\left(\mathrm{cm}^{-1}\right): 3351$ (medium, O-H), 1596 (medium $\mathrm{C}=\mathrm{C}$ ), 1475, 1337 and 1161 (strong, $\mathrm{S}=\mathrm{O}$ ), 1088, 990, 713, 664, 586, 548; MS $(\mathrm{m} / z)(\mathrm{EI}, 70 \mathrm{eV})$ (relative intensity): 91 (100), 155 (85), 262 (25), 139 (35), 388 (M-1, 40).

4-Chloro-N-hydroxy-N-(4-iodophenyl)benzenesulfonamide (3b) Pale yellow; MP: $154-156{ }^{\circ} \mathrm{C} ;{ }^{1} \mathrm{H}$ NMR: $\delta \mathrm{ppm}$ $\left(500 \mathrm{MHz}, \mathrm{CD}_{3} \mathrm{CO}-d_{3}\right): 7.01$ (d, $J=10,2 \mathrm{H}$, aromatic), 7.55 (d, $J=10 \mathrm{~Hz}, 2 \mathrm{H}$, aromatic), $7.61(\mathrm{~d}, J=10 \mathrm{~Hz}, 2 \mathrm{H}$, aromatic), $7.68\left(\mathrm{~d}, J=10 \mathrm{~Hz}, 2 \mathrm{H}\right.$, aromatic), $10.38(\mathrm{~s}, 1 \mathrm{H}, \mathrm{OH}) ;{ }^{13} \mathrm{C}$ NMR: $\delta$ ppm $\left(125 \mathrm{MHz}, \mathrm{CD}_{3} \mathrm{CO}-d_{3}: 91.5\right.$, 124.6, 124.9 , 128.9, 131.2, 137.4, 138.9, 140.0, 142.6; IR (KBr) $\left(\mathrm{cm}^{-1}\right)$ : 3357 (medium, O-H), 1571 (medium $\mathrm{C}=\mathrm{C}), 1476,1344$ and 1165 (strong, $\mathrm{S}=\mathrm{O}), 1091,992,829,759,620,557 ; \mathrm{MS}(\mathrm{m} / z)(\mathrm{EI}, 70 \mathrm{eV})$ (relative intensity): 111 (100), 175 (90), 282 (25), 393 (15), 408 (M-1, 40).

$N$-(4-Chlorophenyl)-N-hydroxybenzenesulfonamide (1c) Pale yellow; MP: $102-104{ }^{\circ} \mathrm{C} ;{ }^{1} \mathrm{H}$ NMR: $\delta \mathrm{ppm}$ $\left(500 \mathrm{MHz}, \mathrm{CD}_{3} \mathrm{CO}-d_{3}\right): 7.18(\mathrm{~d}, J=10 \mathrm{~Hz}, 2 \mathrm{H}$, aromatic), $7.33(\mathrm{~d}, J=10,2 \mathrm{H}$, aromatic), $7.57(\mathrm{~m}, 4 \mathrm{H}$, aromatic), $7.73\left(\mathrm{~m}, 1 \mathrm{H}\right.$, aromatic), $10.29(\mathrm{~s}, 1 \mathrm{H}, \mathrm{OH}) ;{ }^{13} \mathrm{C} \mathrm{NMR}: \delta \mathrm{ppm}\left(125 \mathrm{MHz}, \mathrm{CD}_{3} \mathrm{CO}-d_{3}: 124.2,128.2,128.5,129.5\right.$, 132.0, 132.8, 134.0, 141.8; IR (KBr) $\left(\mathrm{cm}^{-1}\right)$ : 3335 (medium, $\left.\mathrm{O}-\mathrm{H}\right), 1584$ (medium $\mathrm{C}=\mathrm{C}$ ), 1481, 1348 and 1179 (strong, $\mathrm{S}=\mathrm{O}), 1087,1015,831,737,608,559,577$; MS $(\mathrm{m} / \mathrm{z})$ (EI, $70 \mathrm{eV})$ (relative intensity): $142(100), 77(70)$, $111(45), 267(10), 283(\mathrm{M}, 15)$.

$\mathrm{N}$-(4-Chlorophenyl)-N-hydroxy-4-methylbenzenesulfonamide (2c) Pale yellow; MP: $129-130{ }^{\circ} \mathrm{C} ;{ }^{1} \mathrm{H}$ NMR: $\delta$ ppm $\left(500 \mathrm{MHz}, \mathrm{CD}_{3} \mathrm{CO}-d_{3}\right): 2.42(\mathrm{~S}, 3 \mathrm{H}$, methyl), 7.19 (d, $J=10,2 \mathrm{H}$, aromatic), $7.32(\mathrm{~d}, J=10 \mathrm{~Hz}, 2 \mathrm{H}$, aromatic), $7.35\left(\mathrm{~d}, J=10 \mathrm{~Hz}, 2 \mathrm{H}\right.$, aromatic), $7.43\left(\mathrm{~d}, J=10 \mathrm{~Hz}, 2 \mathrm{H}\right.$, aromatic), $10.23(\mathrm{~s}, 1 \mathrm{H}, \mathrm{OH}) ;{ }^{13} \mathrm{C}$ NMR: $\delta$ ppm $(125 \mathrm{MHz}$, $\mathrm{CD}_{3} \mathrm{CO}-d_{3}: 20.5,124.1,128.2,129.1,129.5,129.9,131.8,141.9,145.0 ; \mathrm{IR}(\mathrm{KBr})\left(\mathrm{cm}^{-1}\right): 3346$ (medium, O-H), 2926 (weak, $\mathrm{CH}_{3}$ ) 1595 (medium $\mathrm{C}=\mathrm{C}$ ), 1482, 1342 and 1163 (strong, $\mathrm{S}=\mathrm{O}$ ), 1086, 889, 831, 814, 731, 671, 555; MS ( $m / z)(E I, 70 \mathrm{eV})$ (relative intensity): 91 (100), 142 (90), 111 (60), 65 (60), 281(30), 297 (M-1, 15).

4-Chloro-N-(4-chlorophenyl)-N-hydroxybenzenesulfonamide (3c) Pale yellow; MP: $142-146{ }^{\circ} \mathrm{C} ;{ }^{1} \mathrm{H}$ NMR: $\delta$ ppm $\left(500 \mathrm{MHz}, \mathrm{CD}_{3} \mathrm{CO}-d_{3}\right): 7.20(\mathrm{~d}, J=10,2 \mathrm{H}$, aromatic), 7.35 (d, $J=10 \mathrm{~Hz}, 2 \mathrm{H}$, aromatic), $7.55(\mathrm{~d}, J=10 \mathrm{~Hz}$, $2 \mathrm{H}$, aromatic), $7.61\left(\mathrm{~d}, J=10 \mathrm{~Hz}, 2 \mathrm{H}\right.$, aromatic), $10.39(\mathrm{~s}, 1 \mathrm{H}, \mathrm{OH}) ;{ }^{13} \mathrm{C}$ NMR: $\delta$ ppm $\left(125 \mathrm{MHz}, \mathrm{CD}_{3} \mathrm{CO}-d_{3}\right.$ : 124.2, 128.4, 128.9 , 131.2, 131.4, 132.2, 140.0, 141.5; IR (KBr) $\left(\mathrm{cm}^{-1}\right): 3349$ (medium, O-H), 1574 (medium $\mathrm{C}=\mathrm{C}$ ), 1482, 1350 and 1182 (strong, $\mathrm{S}=\mathrm{O}), 1090,1013,834,760,638,589,562$; MS $(\mathrm{m} / z)(\mathrm{EI}, 70 \mathrm{eV})$ (relative intensity): 111 (100), 175 (85), 142 (25), 301 (10), 316 (M-1, 20). 

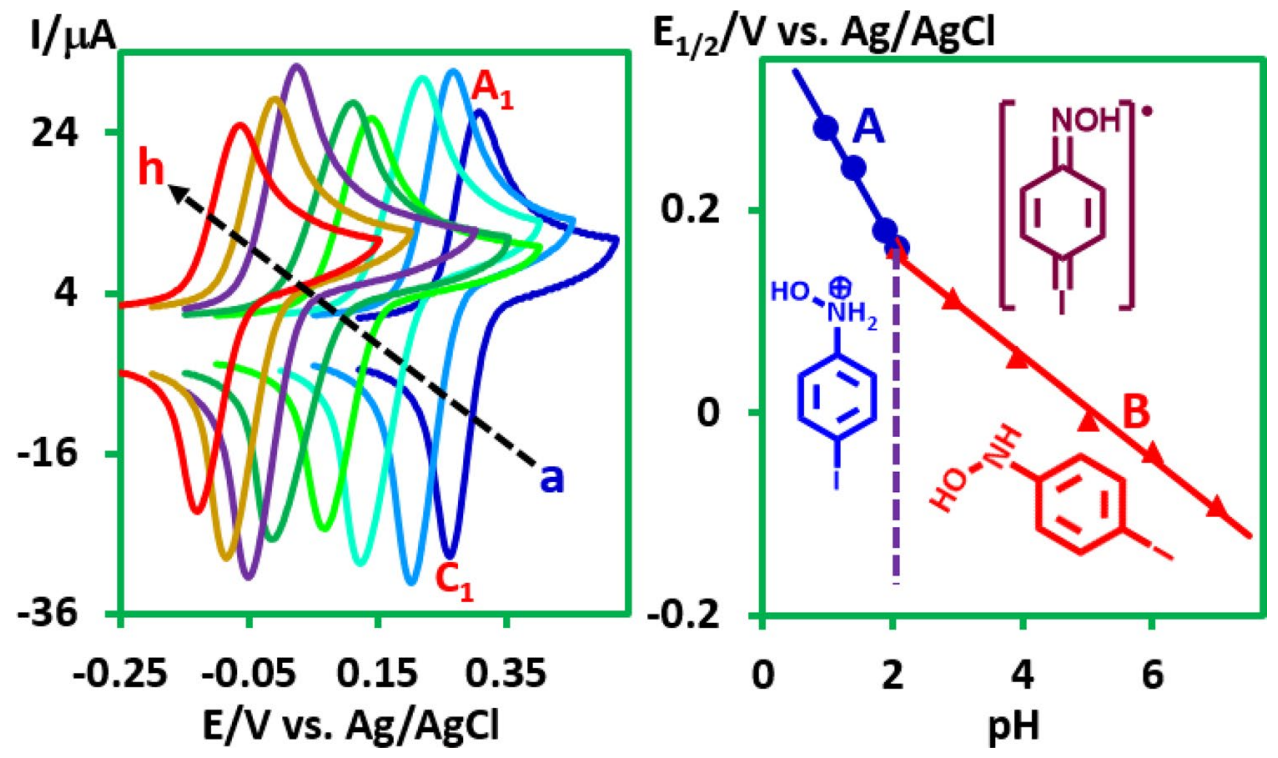

Figure 4. Left: cyclic voltammograms of PINB (1.0 mM) in buffer solution with various $\mathrm{pH}$ values/acetonitrile $(50 / 50, \mathrm{v} / \mathrm{v})$ mixture. $\mathrm{pH}$ values from a to $\mathrm{h}$ are: $0.97,1.40,1.87,2.93,3.90,5.00,6.00$ and 7.00 . Scan rate: $10 \mathrm{mV} / \mathrm{s}$, at glassy carbon electrode, Temperature, $25 \pm 1{ }^{\circ} \mathrm{C}$. Right: Pourbaix diagram for PINB. This figure was prepared by Microsoft Excel (OFFICE 2013).

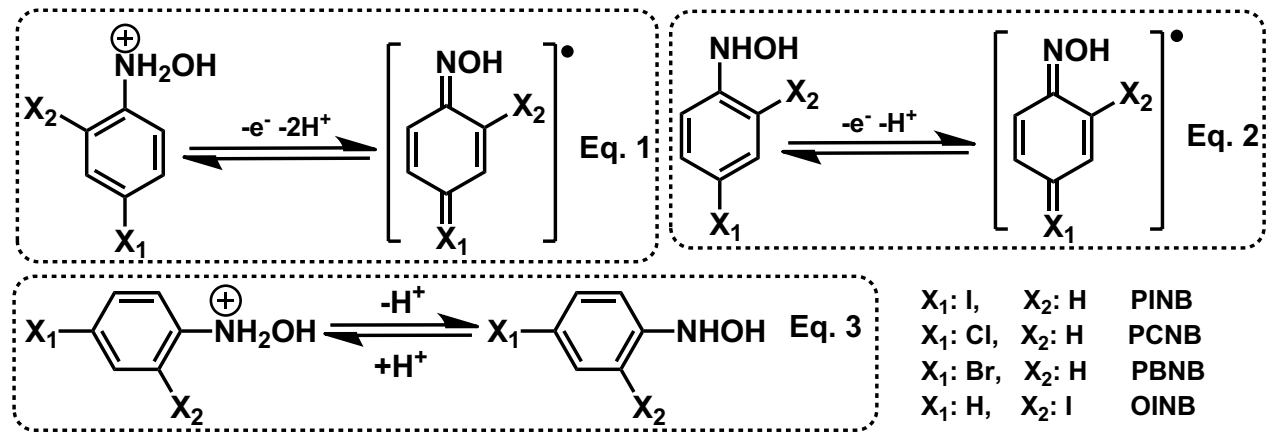

Figure 5. Oxidation/reduction and acid/base behaviors of halophenylhydroxylamines at different $\mathrm{pH}$ values. The structures of the compounds were drawn using ChemOffice 12.0 (CambridgeSoft).

N-Hydroxy-N-(2-iodophenyl)benzenesulfonamide (1d) Pale yellow; MP: $142-144{ }^{\circ} \mathrm{C} ;{ }^{1} \mathrm{H}$ NMR: $\delta$ ppm $\left(500 \mathrm{MHz}, \mathrm{CD}_{3} \mathrm{CO}-d_{3}\right): 6.78(\mathrm{~d}, J=10 \mathrm{~Hz}, 1 \mathrm{H}$, aromatic), $7.11(\mathrm{t}, 1 \mathrm{H}$, aromatic), $7.30(\mathrm{t}, 1 \mathrm{H}$, aromatic), 7.68 (m, $2 \mathrm{H}$, aromatic), $7.81\left(\mathrm{~m}, 3 \mathrm{H}\right.$, aromatic), $7.98(\mathrm{~d}, \mathrm{~J}=10 \mathrm{~Hz}, 1 \mathrm{H}$, aromatic $), 10.19(\mathrm{~s}, 1 \mathrm{H}, \mathrm{OH}) ;{ }^{13} \mathrm{C} \mathrm{NMR}: \delta$ ppm $\left(125 \mathrm{MHz}, \mathrm{CD}_{3} \mathrm{CO}-d_{3}: 99.0,126.3,128.5,128.7,130.1,130.3,134.3,139.6,144.5 ; \mathrm{IR}(\mathrm{KBr})\left(\mathrm{cm}^{-1}\right): 3329\right.$ (medium, O-H), 1451 (medium $\mathrm{C}=\mathrm{C}$ ), 1350 and 1175 (strong, $\mathrm{S}=\mathrm{O}), 1087,908,767,692,571$; MS $(\mathrm{m} / z)(\mathrm{EI}$, $70 \mathrm{eV}$ ) (relative intensity): 224 (100), 203 (80), 218 (40), 359 (40), 375 (M, 25).

$\mathrm{N}$-Hydroxy-N-(2-iodophenyl)-4-methylbenzenesulfonamide (2d) Pale yellow; MP: $162-164{ }^{\circ} \mathrm{C} ;{ }^{1} \mathrm{H}$ NMR: $\delta$ ppm (500 MHz, $\left.\mathrm{CD}_{3} \mathrm{CO}-d_{3}\right): 2.49(\mathrm{~S}, 3 \mathrm{H}$, methyl), 7.1 (t, $1 \mathrm{H}$, aromatic), 7.29 (t, $1 \mathrm{H}$, aromatic), $7.45(\mathrm{~d}, J=10 \mathrm{~Hz}$, $2 \mathrm{H}$, aromatic), $7.68\left(\mathrm{~d}, J=10 \mathrm{~Hz}, 2 \mathrm{H}\right.$, aromatic), $7.94\left(\mathrm{~d}, J=10 \mathrm{~Hz}, 2 \mathrm{H}\right.$, aromatic), $10.19(\mathrm{~s}, 1 \mathrm{H}, \mathrm{OH}) ;{ }^{13} \mathrm{C}$ NMR: $\delta$ ppm $\left(125 \mathrm{MHz}, \mathrm{CD}_{3} \mathrm{CO}-d_{3}: 99.0,126.2,128.5,129.2,130.2,131.3,139.5,144.6,145.1 ; \mathrm{IR}(\mathrm{KBr})\left(\mathrm{cm}^{-1}\right): 3337\right.$ (medium, O-H), 1463 (medium $\mathrm{C}=\mathrm{C}$ ), 1344 and 1165 (strong, $\mathrm{S}=\mathrm{O}$ ), 1087, 769, 710, 665, 577; MS $(\mathrm{m} / \mathrm{z})(\mathrm{EI}$, $70 \mathrm{eV}$ ) (relative intensity): 223 (100), 203 (60), 91 (70), 373 (20), 389 (M, 25).

4-Chloro-N-hydroxy-N-(2-iodophenyl)benzenesulfonamide (3d) Pale yellow; MP: $154-156{ }^{\circ} \mathrm{C} ;{ }^{1} \mathrm{H}$ NMR: $\delta$ ppm $\left(500 \mathrm{MHz}, \mathrm{CD}_{3} \mathrm{CO}-d_{3}\right): 6.84(\mathrm{~d}, J=10 \mathrm{~Hz}, 1 \mathrm{H}$, aromatic), 7.13 (t, $1 \mathrm{H}$, aromatic), $7.34(\mathrm{t}, 1 \mathrm{H}$, aromatic), 7.71 (d, $\mathrm{J}=10,2 \mathrm{H}$, aromatic), $7.81\left(\mathrm{~d}, \mathrm{~J}=10,2 \mathrm{H}\right.$, aromatic), $7.96\left(\mathrm{~d}, \mathrm{~J}=10 \mathrm{~Hz}, 1 \mathrm{H}\right.$, aromatic), $10.19(\mathrm{~s}, 1 \mathrm{H}, \mathrm{OH}) ;{ }^{13} \mathrm{C}$ NMR: $\delta$ ppm $\left(125 \mathrm{MHz}, \mathrm{CD}_{3} \mathrm{CO}-d_{3}\right)$ : 99.0, 126.1, $128.7,129.0,130.4,131.8,132.8,139.6,140.1,144.2 ; \mathrm{IR}(\mathrm{KBr})$ $\left(\mathrm{cm}^{-1}\right): 3350$ (medium, O-H), 1464 (medium C=C), 1348 and 1172 (strong, $\mathrm{S}=\mathrm{O}$ ), 1091, 764, 707, 640, 574; MS $(\mathrm{m} / z)($ EI, $70 \mathrm{eV})$ (relative intensity): 223 (100), 203 (75), 111(60), $393(20), 409(\mathrm{M}, 15)$.

$N$-(4-Bromophenyl)-N-hydroxybenzenesulfonamide (1e) Pale yellow; MP: $92-94{ }^{\circ} \mathrm{C} ;{ }^{1} \mathrm{H}$ NMR: $\delta$ ppm $\left(500 \mathrm{MHz}, \mathrm{CD}_{3} \mathrm{CO}-d_{3}\right): 7.14(\mathrm{~d}, J=10 \mathrm{~Hz}, 2 \mathrm{H}$, aromatic), $7.51(\mathrm{~d}, J=10 \mathrm{~Hz}, 2 \mathrm{H}$, aromatic), $7.58(\mathrm{~m}, 4 \mathrm{H}$, aromatic),7.75 (m, $1 \mathrm{H}$, aromatic), $10.31(\mathrm{~s}, 1 \mathrm{H}, \mathrm{OH}) ;{ }^{13} \mathrm{C} \mathrm{NMR}: \delta \mathrm{ppm}\left(125 \mathrm{MHz}, \mathrm{CD}_{3} \mathrm{CO}-d_{3}\right): 119.9,124.5,128.6$, 

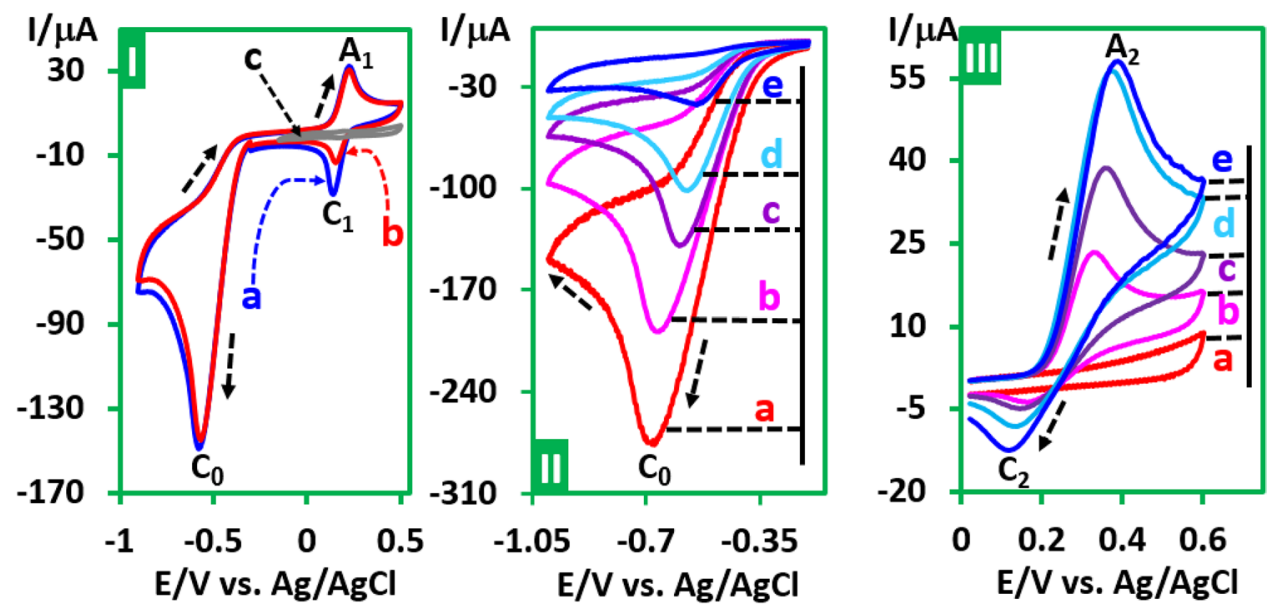

Figure 6. Part I: Cyclic voltammograms of PINB ( $1.0 \mathrm{mM})$ : (a) in the absence, $(\mathbf{b})$ in the presence of BSA $(1.0 \mathrm{mM})$ and (c) cyclic voltammogram of BSA $(1.0 \mathrm{mM})$. Scan rate: $10 \mathrm{mV} / \mathrm{s}$. Part II. Cyclic voltammograms of PINB $(0.5 \mathrm{mmol})$ in the presence of BSA $(0.5 \mathrm{mmol})$ during controlled-potential coulometry at $-0.8 \mathrm{~V}$ vs. $\mathrm{Ag} / \mathrm{AgCl}$. Scan rate: $100 \mathrm{mV} / \mathrm{s}$.Part III: Similar to part II, but when scanning the potential from 0.0 to $+0.60 \mathrm{~V}$. Voltammograms in parts II and III are taken after consumption of: (a) 0, (b) 50, (c) 100, (d) 150 and (e) 200 C. Solvent: water (phosphate buffer, $\mathrm{pH}, 2.0, c=0.2 \mathrm{M}) /$ acetonitrile $(50 / 50 \mathrm{v} / \mathrm{v})$ at room temperature. Working electrode: GC electrode. This figure was prepared by Microsoft Excel (OFFICE 2013).

129.5, 131.3, 132.8, 134.0, 142.3; IR ( $\mathrm{KBr})\left(\mathrm{cm}^{-1}\right)$ : 3341 (medium, $\left.\mathrm{O}-\mathrm{H}\right), 1480$ (medium $\left.\mathrm{C}=\mathrm{C}\right), 1342$ and 1163 (strong, $\mathrm{S}=\mathrm{O}), 1069,886,720,667,591 ; \mathrm{MS}(\mathrm{m} / \mathrm{z})(\mathrm{EI}, 70 \mathrm{eV})$ (relative intensity): 77 (100), 141 (40), 51 (50), $311(10), 326(\mathrm{M}, 25)$.

N-(4-Bromophenyl)-N-hydroxy-4-methylbenzenesulfonamide (2e) Pale yellow; MP: $113-114{ }^{\circ} \mathrm{C} ;{ }^{1} \mathrm{H}$ NMR: $\delta$ ppm $\left(500 \mathrm{MHz}, \mathrm{CD}_{3} \mathrm{CO}-d_{3}\right): 2.44(\mathrm{~S}, 3 \mathrm{H}$, methyl), 7.15 (d, $J=10,2 \mathrm{H}$, aromatic), 7.37 (d, $J=10 \mathrm{~Hz}, 2 \mathrm{H}$, aromatic), $7.45\left(\mathrm{~d}, J=10 \mathrm{~Hz}, 2 \mathrm{H}\right.$, aromatic), $7.49\left(\mathrm{~d}, J=10 \mathrm{~Hz}, 2 \mathrm{H}\right.$, aromatic), $10.24(\mathrm{~s}, 1 \mathrm{H}, \mathrm{OH}),{ }^{13} \mathrm{C}$ NMR: $\delta$ ppm $(125 \mathrm{MHz}$, $\mathrm{CD}_{3} \mathrm{CO}-d_{3}: 21.0,119.7,124.4,129.2,129.6,129.9,131.2,142.8,145.0 ; \mathrm{IR}(\mathrm{KBr})\left(\mathrm{cm}^{-1}\right)$ : 3341 (medium, O-H), 1480 (medium $\mathrm{C}=\mathrm{C}$ ), 1342 and 1163 (strong, $\mathrm{S}=\mathrm{O}$ ), 1069, 987, 667, 591, 553; MS $(\mathrm{m} / z)(\mathrm{EI}, 70 \mathrm{eV})$ (relative intensity): 91 (100), 155 (80), 187 (60), 327 (50), 343 (M, 25).

\section{Results and discussion}

Cyclic voltammograms (CVs) of $p$-iodonitrobenzene (PINB), $p$-chloronitrobenzene (PCNB), $p$-bromonitrobenzene $(\mathbf{P B N B})$ and $o$-iodonitrobenzene $(\mathbf{O I N B})$ in aqueous phosphate buffer $(\mathrm{pH}, 2.0, c=0.2 \mathrm{M}) /$ acetonitrile $(50 / 50 \mathrm{v} / \mathrm{v})$ are shown in Fig. 2 . The voltammograms consist of an irreversible cathodic peak $\left(\mathrm{C}_{0}\right)$ which is correspond to a four-electron reduction of nitro group to hydroxylamine group ${ }^{36-39}$ and a reversible couple $\left(A_{1} /\right.$ $\mathrm{C}_{1}$ ), at a more positive potential.

The redox behavior of $A_{1} / C_{1}$ is shown in Fig. 3. Two pathways are possible for the oxidation of cathodically generated phenylhydroxylamine; (1) one-electron oxidation and the formation of phenylhydroxylamine radical (PHR) (path A) and (2) two-electron oxidation and the formation of nitrosobenzene derivatives (NSB) (path B).

In order to identify the more probable oxidation pathway, the number of electrons exchanged in the oxidation of $\mathrm{N}$-(4-iodophenyl)hydroxylamine was calculated using differential pulse voltammetry (DPV) method (Supplementary Fig. S1), by measuring half-peak width $\left(W_{1 / 2}\right)$ according to equation ${ }^{40}$ :

$$
W_{1 / 2}=3.52 R T / n F \text {. }
$$

The result of this experiment is in agreement with the one-electron transfer in the oxidation step of $N$-(4-iodophenyl)hydroxylamine and confirms the formation of phenylhydroxylamine radical (PHR) under our experimental conditions. The structures of PHR and NSB were optimized at B3LYP/6-311G level of theory by using guassian09W (Supplementary Fig. S2). The relative Gibbs free energies of PHR and NSB were found to be 15.1 and $0.0 \mathrm{kcal} / \mathrm{mol}$, respectively, which is another confirmation of the formation of PHR. The effect of solution $\mathrm{pH}$ on the half-wave potential $\left(E_{1 / 2}\right)$ of $N$-(4-iodophenyl)hydroxylamine (PIPHA) and other phenyl hydroxylamines produced from the reduction of PCNB, PBNB, and OINB was evaluated in the range of 1-7 (Fig. 4 and Supplementary Figs. S3-S5). It was found that half-wave potential $\left(E_{1 / 2}\right)$ of PINB shifted to negative values with increasing $\mathrm{pH}$ which indicates that proton is involved in the electrode process. The Pourbaix diagram of PIPHA is also shown in Fig. 4. It consists of two lines with slopes 113 (line A) and 52 (line B) mV/pH (Fig. 5). The slope of $113 \mathrm{mV} / \mathrm{pH}$ is consistent with the theoretical value for a one-electron/two-proton process $(118 \mathrm{mV} /$ $\mathrm{pH}$ ). On the other hand, the slope of $52 \mathrm{mV} / \mathrm{pH}$ (line $\mathrm{B}$ ) is in accordance with the one-electron/one-proton process $(59 \mathrm{mV} / \mathrm{pH})$.

Also, the $\mathrm{pK}_{\mathrm{a}}$ values of protonated PIPHA, PCPHA, PBPHA and OIPHA are 2.06, 1.97, 1.97 and 2.10, respectively. Details for other phenylhydroxylamines are shown in Supplementary Figs. S3-S5. 

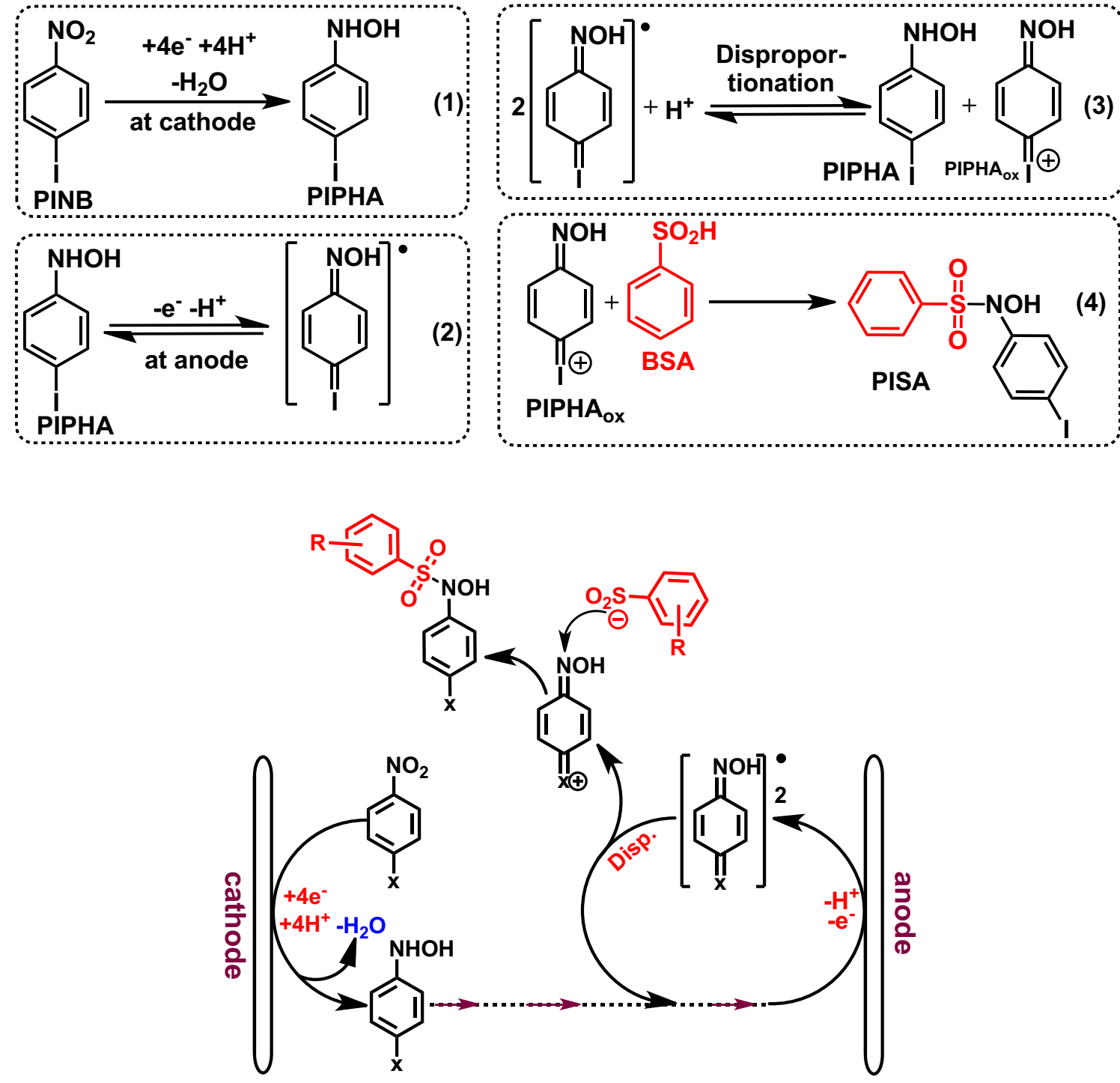

Figure 7. Electrochemical reaction mechanism of PINB in the presence of BSA. The structures of the compounds were drawn using ChemOffice 12.0 (CambridgeSoft).

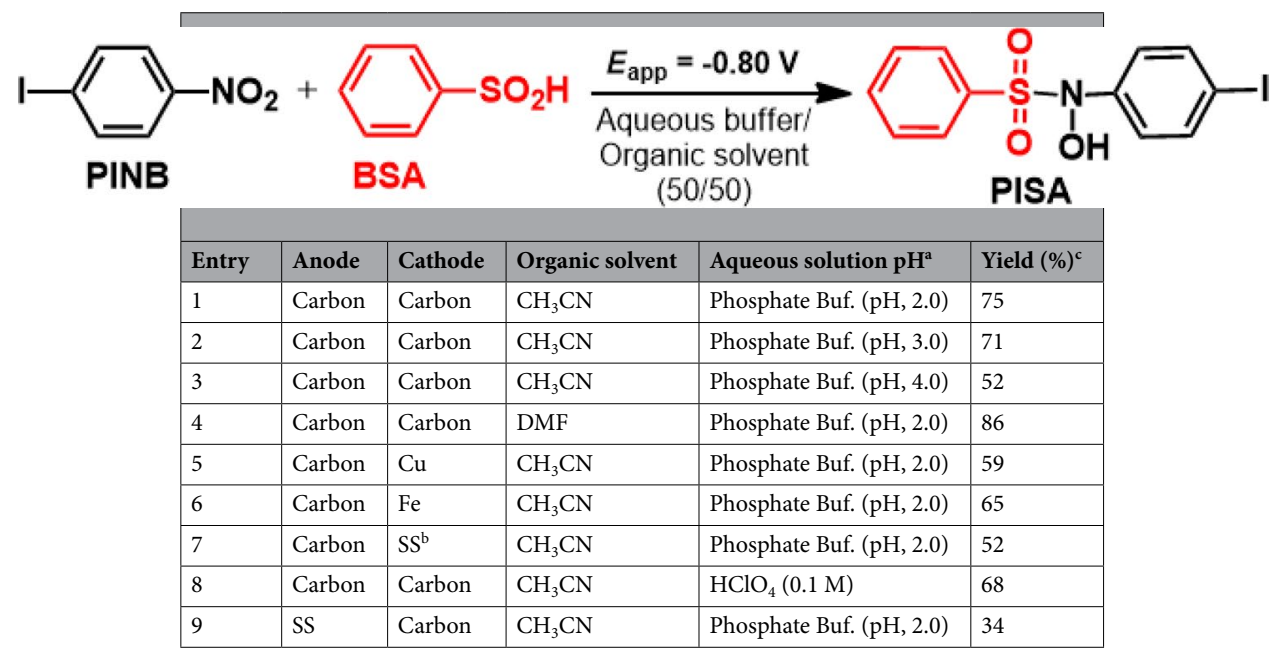

Table 1. Optimization of conditions for the synthesis of PISA. The structures of the compounds were drawn

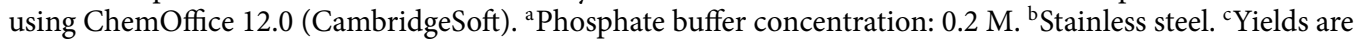
calculated based on the weight of isolated products after work-up. 


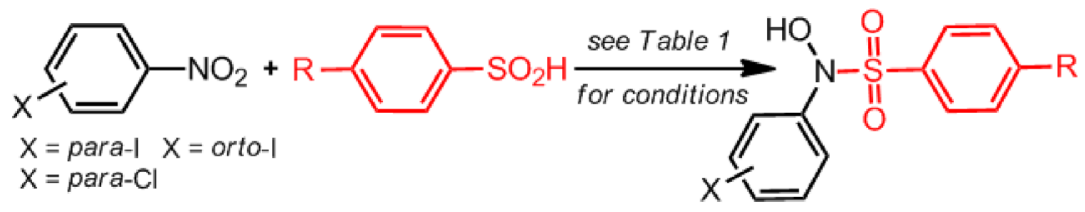

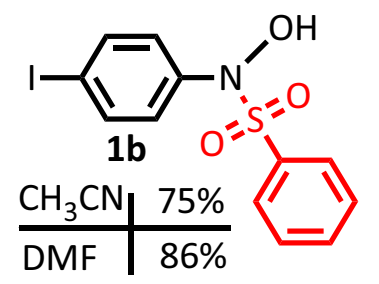

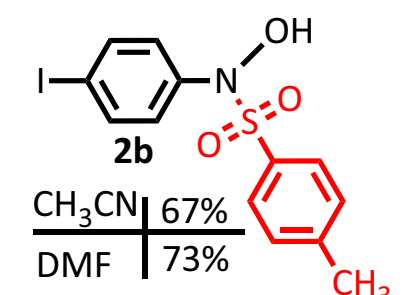

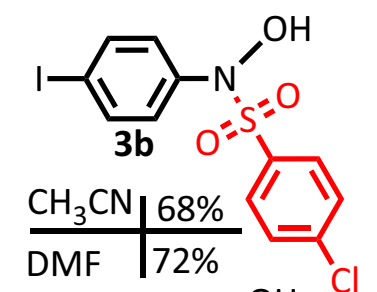<smiles>CC(C)(C)[N+]([O-])([O-])[O-]</smiles><smiles>Cc1ccc(S(=O)(=O)N(O)c2ccc(Cl)cc2)cc1</smiles><smiles>CC(C)(C)[R6]([O-])([O-])[O-]</smiles>

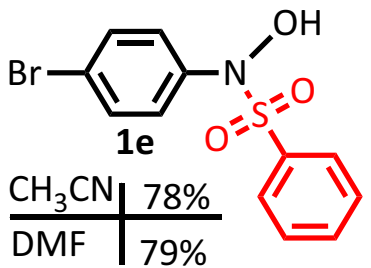<smiles>[Z6]c1cccc(N(O)S(=O)(=O)c2ccc(C)cc2)c1N(O)S(=O)(=O)c1ccc(Br)cc1</smiles><smiles>CC(C)(C)[N+]([O-])([O-])[O-]</smiles>

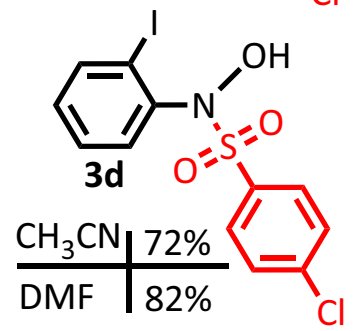

Table 2. Scope of the halosulfonamide synthesis. In an undivided cell equipped with four carbon rods as cathode and one carbon rod as anode, a solution $(c a .80 \mathrm{~mL}$ ) of water (phosphate buffer, $\mathrm{pH}, 2.0, c=0.2 \mathrm{M}$ )/ acetonitrile $(50 / 50 \mathrm{v} / \mathrm{v})$ containing halonitrobenzene $(0.5 \mathrm{mM})$ and arylsulfinic acid $(0.5 \mathrm{mM})$ was electrolyzed at $-0.8 \mathrm{~V}$ vs. $\mathrm{Ag} / \mathrm{AgCl}$. The structures of the compounds were drawn using ChemOffice 12.0 (CambridgeSoft).

The cyclic voltammogram of PINB in the presence of benzenesulfinic acid (BSA) as a nucleophile is shown in Fig. 6, part I, curve b. Comparison of this voltammogram with that of in the absence of BSA shows that $I_{\mathrm{pC} 1}$ decreases significantly. This decrease confirms the reaction between oxidized hydroxylamine and BSA.

Controlled-potential coulometry was performed in a solution containing PINB ( $0.5 \mathrm{mmol})$ and BSA $(0.5 \mathrm{mmol})$ at $-0.8 \mathrm{~V}$ versus $\mathrm{Ag} / \mathrm{AgCl}$. The electrolysis progress was monitored by cyclic voltammetry (Fig. 6 , parts II and III). Part II shows a continuous decrease in cathodic peak $\mathrm{C}_{0}$ current over the charge passed due to the reduction of the nitro group to hydroxylamine. On the other hand, part III shows a continuous increase of the peaks $\mathrm{A}_{2}$ and $\mathrm{C}_{2}$ currents with increasing amounts of charge.

The proposed mechanism for the oxidation of PINB in the presence of BSA is shown in Fig. 7. According to this mechanism, cathodically generated PIPHA at the anode surface is oxidized to its corresponding radical. The disproportionation of the PIPHA radicals in the next step, to yield the starting PIPHA and 4-(hydroxyimino) cyclohexa-2,5-dien-1-ylidene) iodonium (PIPHA $\left.\mathbf{A x}_{\mathbf{o x}}\right)$. The reaction of $\mathbf{P I P H A}_{\mathbf{o x}}$ as an acceptor with $\mathbf{B S A}(\mathrm{R}=\mathrm{H})$ affording the corresponding iodosulfonamide (PISA).

The optimization of conditions for the electrochemical synthesis of PISA by the change in the electrode material, solvent and aqueous solution $\mathrm{pH}$ was studied and the results are shown in Table 1. PISA was achieved in $75 \%$ yield with carbon electrodes in aqueous phosphate buffer $(\mathrm{pH}, 2.0, c=0.2 \mathrm{M})$ /acetonitrile mixture $(50 / 50$ $\mathrm{v} / \mathrm{v}$ ) (entry 1 ). DMF as a co-solvent also afforded the product in $86 \%$ yield (entry 4 ). We think that $\mathrm{pH}$ is the most important factor for increasing yield, by preventing or minimizing side reactions such as PIPHA-PIPHA coupling reaction. At pH 2, PIPHA is mostly protonated (Fig. 2) and cannot act as an effective nucleophile to 
compete with the reaction of BSA with PIPHA ox $_{\text {. At }}$ PH 2, the use of electrodes other than carbon and solvents other than DMF, reduce yield. With the optimized conditions in hand, we investigated the scope of the reaction using a range of halonitroarenes and sulfinic acids (Table 2). The data presented in Table 2 show that we were able to develop an efficient method to synthesize new halosulfonamides in a one-pot reaction with a $63-86 \%$ overall yield.

As shown in Table 2, a number of halo- $N$-hydroxy sulfonamides have been synthesized in a one-pot process for the first time. No data have been reported so far for the electrochemically synthesis of these types of sulfonamides. The reaction is carried out under mild conditions at room temperature and atmospheric pressure with a high atom economy and without using inorganic (or organic) oxidizing agents or catalysts. Selective electrohydrogenation of halonitroarenes (without removal of halogen) is another achievement of this method. Compared with the literature procedures (Supplementary Table S1) that require amines, metal catalysts, high temperatures, expensive, unstable and toxic reagents, this method operates under mild and sustainable reaction conditions and utilizes low-cost materials which is suitable for scalable production.

\section{Conclusions}

In this study, a ping pong reaction mechanism is proposed, which in its first stage the halonitroarene is reduced at the cathode to related hydroxylamine and then the oxidation of cathodically generated hydroxylamine along with the disproportionation reaction to form the halonium acceptor. The reaction of halonium compound with arylsulfinic acids affording the corresponding halo- $N$-hydroxysulfonamide. In this new strategy, we utilized the primary electrochemical principles for the synthesis of a new type of sulfonamids. These compounds have not been synthesized electrochemically so far and therefore, we were interested in the synthesis of them. In this paper, we also reported the first example of in situ generation and reaction of the unstable hydroxyimino-cyclohexa-dienylidenehaloniums intermediates for the synthesis of organic compounds. This method has several unique features which are: (1) Synthesis of halo- $N$-hydroxysulfonamide derivatives. This class of compounds had not yet been synthesized electrochemically. (2) This is the first example of in situ generation of the unstable hydroxyiminocyclohexa-dien-ylidenehaloniums intermediates without using any metal catalyst and electrochemical detection of them. (3) The reaction mechanism reported for the synthesis of halo- $N$-hydroxysulfonamide compounds (Fig. 7), including cathodic reduction, anodic oxidation, disproportionation, and addition reaction is unique and it has not been reported elsewhere. (5) The electrochemical data reported for halonitrobenzenes, PINB, PCNB, PBNB and OINB and also electrogenerated $N$-(halophenyl)hydroxylamines, PIPHA, PCPHA, PBPHA and OIPHA, are unique and they have not been reported elsewhere. (6) This protocol describes a detailed procedure for the formation of haloniums intermediates and provides a novel approach for the synthesis of halo$\mathrm{N}$-hydroxysulfonamide derivatives in sustainable and facile conditions.

Received: 29 May 2020; Accepted: 6 October 2020

Published online: 21 October 2020

\section{References}

1. Benedetti P. G. D. In Advances in Drug Research. Vol. 16 (ed. Testa, B.) 227-279 (Academic Press, London, 1987).

2. Caddick, S. J., Wilden, D. \& Judd, D. B. Direct synthesis of sulfonamides and activated sulfonate esters from aulfonic acids. J. Am. Chem. Soc. 126, 1024-1025 (2004).

3. DeBergh, J. R., Niljianskul, N. \& Buchwald, S. L. Synthesis of aryl sulfonamides via palladium-catalyzed chlorosulfonylation of arylboronic acids. J. Am. Chem. Soc. 135, 10638-10641 (2013).

4. Tang, X. D. et al. Copper-catalyzed sulfonamides formation from sodium sulfinates and amines. Chem. Commun. 49, 6102-6104 (2013).

5. Reddy, R. J., Shankar, A., Waheed, M. \& Nanubolu, J. B. Metal-free, highly regioselective sulfonylation of NH-1,2,3-triazoles with sodium sulfinates and thiosulfonates. Tetrahedron. Lett. 59, 2014-2017 (2018).

6. Fu, L. et al. Synthesis of sulfonamides from azoles and sodium sulfinates at ambient temperature. Tetrahedron. Lett. 73, 2504-2511 (2017).

7. Chen, J. et al. Iodine-catalyzed sulfonylation of sulfonyl hydrazides with tert-amines: A green and efficient protocol for the synthesis of sulphonamides. RSC Adv. 9, 31212-31216 (2019).

8. Mulina, O. M., Ilovaisky, A. I. \& Terent'ev, A. O. Oxidative coupling with S-N bond formation. Eur. J. Org. Chem. 2018, 4648-4672 (2018).

9. Fu, Y. et al. NaI-catalyzed oxidative amination of aromatic sodium sulfinates: Synergetic effect of ethylene dibromide and air as oxidants. Eur. J. Org. Chem. 2018, 6966-6970 (2018).

10. Wu, S., Zhang, Y., Zhu, M. \& Yan, J. One-pot synthesis of sulfonamides from sodium sulfinates and amines via sulfonyl bromides. Synlett 27, 2699-2704 (2016).

11. Nematollahi, D. \& Maleki, A. Electrochemical oxidaton of N, N-dialkyl-p-phenylenediamines in the presence of arylsulfinic acids. An efficient method for the synthesis of new sulfonamide derivatives. Electrochem. Commun. 11, 488-491 (2009).

12. Varmaghani, F., Nematollahi, D., Mallakpour, S. \& Esmaili, R. Electrochemical oxidation of 4-substituted urazoles in the presence of arylsulfinic acids: An efficient method for the synthesis of new sulfonamide derivatives. Green Chem. 14, 963-967 (2012).

13. Beiginejad, H. \& Nematollahi, D. Electrochemical synthesis of sulfonamide derivatives based on the oxidation of 2, 5-diethoxy4-morpholinoaniline in the presence of arylsulfinic acids. J. Org. Chem. 79, 6326-6329 (2014).

14. Vicente, D. A., Galdino, D., Navarro, M. \& Menezes, P. H. Electrochemical synthesis of sulfonamides in a graphite powder macroelectrode. Green Chem. 22, 5262-5266 (2020).

15. Jiang, Y. et al. Electrochemical oxidative amination of sodium sulfinates: Synthesis of sulfonamides mediated by $\mathrm{NH}_{4} \mathrm{I}$ as a redox catalyst. J. Org. Chem. 81, 4713-4719 (2016).

16. Laudadio, G. et al. Sulfonamide synthesis through electrochemical oxidative coupling of amines and thiols. J. Am. Chem. Soc. 141, 5664-5668 (2019).

17. Youseflouei, N., Alizadeh, S., Masoudi-Khoram, M., Nematollahi, D. \& Alizadeh, H. A comprehensive electrochemical study of 2-mercaptobenzoheterocyclic derivatives. Air-assisted electrochemical synthesis of new sulfonamide derivatives. Electrochim. Acta 353, $136451(2020)$. 
18. Zhu, H., Shen, Y., Deng, Q., Huang, C. \& Tu, T. One-pot bimetallic Pd/Cu-catalyzed synthesis of sulfonamides from boronic acids, DABSO and o-benzoyl hydroxylamines. Chem. Asian J. 12, 706-712 (2017).

19. Konishi, H., Tanaka, H. \& Manabe, K. Pd-catalyzed selective synthesis of cyclic sulfonamides and sulfinamides using $\mathrm{K}_{2} \mathrm{~S}_{2} \mathrm{O}_{5}$ as a sulfur dioxide surrogate. Org. Lett. 19, 1578-1581 (2017).

20. Chen, Y., Murray, P. R. D., Davies, A. T. \& Willis, M. C. Direct copper-catalyzed three-component synthesis of sulfonamides. J. Am. Chem. Soc. 140, 8781-8787 (2018).

21. Wang, X. et al. Copper-catalyzed synthesis of sulfonamides from nitroarenes via the insertion of sulfur dioxide. Chem. Commun. 56, 3437-3440 (2020).

22. Lo, P. K. T., Chen, Y. \& Willis, M. C. Nickel(II)-catalyzed synthesis of sulfinates from aryl and heteroaryl boronic acids and the sulfur dioxide surrogate DABSO. ACS Catal. 9, 10668-10673 (2019).

23. Lo, P. K. T., Oliver, G. A. \& Willis, M. C. Sulfinamide synthesis using organometallic reagents, DABSO, and amines. J. Org. Chem. 85, 5753-5760 (2020).

24. Shi, F. et al. Green and efficient synthesis of sulfonamides catalyzed by nano-Ru/ $\mathrm{Fe}_{3} \mathrm{O}_{4}$. J. Am. Chem. Soc. 131, 1775-1779 (2009).

25. Hayashi, E., Yamaguchi, Y., Kita, Y., Kamata, K. \& Hara, M. One-pot aerobic oxidative sulfonamidation of aromatic thiols with ammonia by a dual-functional $\beta-\mathrm{MnO}_{2}$ nanocatalyst. Chem. Commun. 56, 2095-2098 (2020).

26. Yu, X., Liu, C., Jiang, L. \& Xu, Q. Manganese dioxide catalyzed $\mathrm{N}$-alkylation of sulfonamides and amines with alcohols under air. Org. Lett. 13, 6184-6187 (2011).

27. Kemp-Harper, B. K., Horowitz, J. D. \& Ritchie, R. H. Therapeutic potential of nitroxyl (HNO) donors in the management of acute decompensated heart failure. Drugs 76, 1337-1348 (2016).

28. Guo, C. et al. Development and characterization of a hydroxyl-sulfonamide analogue, 5-chloro- $N$-[2-(4-hydroxysulfamoyl-phenyl)ethyl]-2-methoxy-benzamide, as a novel NLRP3 inflammasome inhibitor for potential treatment of multiple sclerosis. ACS Chem. Neurosci. 8, 2194-2201 (2017).

29. Hauk, A., Richartz, H., Schramm, K. W. \& Fiedler, H. Reduction of nitrated phenols: A method to predict half-wave-potentials of nitrated phenols with molecular modeling. Chemosphere 20, 717-728 (1990).

30. Ferreira, A. I. M. C. L. \& da Silva, M. A. V. R. Experimental and computational study of the thermochemistry of the three iodonitrobenzene isomers. J. Chem. Thermodyn. 59, 94-106 (2013).

31. Song, Q., Wang, W. D., Hu, X. \& Dong, Z. Ru nanoclusters confined in porous organic cages for catalytic hydrolysis of ammonia borane and tandem hydrogenation reaction. Nanoscale 11, 21513-21521 (2019).

32. Li, Y. et al. A green and recyclable ligand-free copper (I) catalysis system for amination of halonitrobenzenes in aqueous ammonia solution. Mol. Catal. 475, 110462 (2019).

33. Wang, Y. et al. Influence of graphene surface chemistry on Ir-catalyzed hydrogenation of p-chloronitrobenzene and cinnamaldehyde: Weak molecule-support interactions. J. Catal. 377, 524-533 (2019).

34. Sandmeyer, T. Ueber die ersetzung der amidgruppe durch chlor in den aromatischen substanzen. Ber. Dtsch. Chem. Ges. 17, $1633-1635$ (1884).

35. Sandmeyer, T. Ueber die ersetzung der amid-gruppe durch chlor, brom und cyan in den aromatischen substanzen. Ber. Dtsch. Chem. Ges. 17, 2650-2653 (1884).

36. Laviron, E. et al. The reduction mechanism of aromatic nitro compounds in aqueous medium: Part II. The reduction of 4-nitropyridine between $\mathrm{H} 0=-6$ and $\mathrm{pH}$ 9.6. J. Electroanal. Chem. 341, 227-255 (1992).

37. Salahifar, E., Nematollahi, D., Bayat, M., Mahyari, A. \& Amiri Rudbari, H. Regioselective green electrochemical approach to the synthesis of nitroacetaminophen derivatives. Org. Lett. 17, 4666-4669 (2015).

38. Mokhtari, B., Nematollahi, D. \& Salehzadeh, H. Paired electrochemical conversion of nitroarenes to sulfonamides, diarylsulfones and bis (arylsulfonyl) aminophenols. Green Chem. 20, 1499-1505 (2018).

39. Mokhtari, B., Nematollahi, D. \& Salehzadeh, H. A tunable pair electrochemical strategy for the synthesis of new benzenesulfonamide derivatives. Sci. Rep. 9, 4537 (2019).

40. Bard, A. J. \& Faulkner, L. R. Electrochemical Methods 2nd edn, 291 (Wiley, New York, 2001).

\section{Acknowledgements}

The authors wish to acknowledge Iran National Science Foundation (INSF) for financial support of this work. The authors also acknowledge the Bu-Ali Sina University Research Council and Center of Excellence in Development of Environmentally Friendly Methods for Chemical Synthesis (CEDEFMCS) for their support of this work.

\section{Author contributions}

H.G. investigation, conceptualization, methodology, writing-original draft. Z.T., A.S. and M.M.K. did some electrochemical experiments. D.N. writing—review \& editing, supervision, project administration.

\section{Competing interests}

The authors declare no competing interests.

\section{Additional information}

Supplementary information is available for this paper at https://doi.org/10.1038/s41598-020-74733-2.

Correspondence and requests for materials should be addressed to D.N.

Reprints and permissions information is available at www.nature.com/reprints.

Publisher's note Springer Nature remains neutral with regard to jurisdictional claims in published maps and institutional affiliations. 
(c) (i) Open Access This article is licensed under a Creative Commons Attribution 4.0 International cc) License, which permits use, sharing, adaptation, distribution and reproduction in any medium or format, as long as you give appropriate credit to the original author(s) and the source, provide a link to the Creative Commons licence, and indicate if changes were made. The images or other third party material in this article are included in the article's Creative Commons licence, unless indicated otherwise in a credit line to the material. If material is not included in the article's Creative Commons licence and your intended use is not permitted by statutory regulation or exceeds the permitted use, you will need to obtain permission directly from the copyright holder. To view a copy of this licence, visit http://creativecommons.org/licenses/by/4.0/.

(C) The Author(s) 2020 